\title{
MENDONGKRAK PROFESIONALISME GURU MELALUI KEGIATAN LESSON STUDY BERBASIS SEKOLAH DI SMPN 2 TALEGONG
}

\author{
CUCU SUWANDANA \\ Kepala SMPN 2 Talegong Kabupaten Garut-Jawa Barat \\ cucuswd@gmail.com
}

\begin{abstract}
ABSTRAK
Tujuan penulisan best practices ini adalah untuk mendongkrak profesionalisme guru melalui model alternatif pelatihan yang menawarkan model in-service training yang lebih fokus pada upaya pemberdayaan guru sesuai dengan kapasitas serta permasalahan yang dihadapi masingmasing, model tersebut adalah lesson Study Berbasis Sekolah (LSBS). Hal ini dilakukan karena pelatihan yang selama ini berjalan tidak efektif dalam meningkatkan profesionalisme guru di SMPN 2 Talegong. Adapun hasil yang dicapai adalah: 1) inovasi dalam perencanaan pembel. Oleh karena itu Lesson Study Berbasis Sekolah (LSBS) adalah solusi terbaik untuk meningkatkan profesionalisme guru, dengan tahapan kegiatannya adalah: 1) tahap Pra-Leson Study yang terdiri dari pembekalan, membentuk kelompok guru, menyusun jadwal, menetapkan guru model; 2) tahap pelaksanaan Lesoon Study, terdiri dari, perencanaan (plan), Pelaksanaan (Do), Refleksi (See) dan dilanjutkan dengan tahapan tindak lanjut. ajaran; 2) inovasi dalam pelaksanaan pembelajaran; 3) inovasi dalam evaluasi pembelajaran; 4) inovasi dalam kepengawasan pembelajaran. Selain itu pelalsanaan LSBS juga berdampak baik terhadap peningkatan profesionalisme guru (kompetensi pedagogik, profesional, kepribadian, dan sosial), dan budaya sekolah (terbangunnya komunitas belajar di lingkungan sekolah, meningkatnya publikasi ilmiah, meningkatnya kepercayaan masyarakat terhadap sekolah, dan tercapainya sasaran kinerja ASN).
\end{abstract}

Kata kunci : Profesionalisme guru, Lesson study Bebasis Sekolah (LSBS)

\section{PENDAHULUAN}

SMP Negeri 2 Talegong merupakan salah satu SMP Negeri terjauh yang berada di Kabupaten Garut, tepatnya berada di ujung barat daya kabupaten Garut yang berbatasan dengan kabupaten Cianjur dan Kabupaten Bandung. Jarak tempuh ke Kecamatan Talegong sejauh $20 \mathrm{KM}$, dan jarak tempuh ke pusat pemerintahan Kabupaten Garut sekitar $160 \mathrm{KM}$. Wilayah Talegong termasuk salah satu daerah yang terbelakang dari berbagai sudut pandang jika dibandingkan dengan daerah-daerah lain yang berada di Kabupaten Garut, Hal ini sejalan dengan Surat Edaran Direktur Jenderal Guru dan Tenaga Kependidikan Kementrian Pendidikan dan Kebudayaan Republik Indonesia tanggal 04 September 2018 tentang Daftar Sekolah Negeri Tertinggal dan Sangat Tertinggal, yang menempatkan SMPN 2 Talegong merupakan sekolah tertinggal.

Walaupun berada di daerah tertinggal dan termasuk sekolah tertinggal, sekolah selalu berusaha untuk meningkatkan kualitas pendidikan supaya bisa mencapai Standar Nasional Pendidikan (SNP). Salah satu prioritasnya adalah peningkatan kualitas gurunya melalui pelatihan, baik pelatihan yang dilakukan oleh pemerintah maupun pelatihan yang dilaksanakan mandiri oleh sekolah. Pemerintah selalu berupaya melakukan peningkatan mutu guru melalui pelatihan-pelatihan dengan pengalokasian anggaran yang tidak sedikit. Sampai saat ini penulis masih merasa prihatin karena seolah-olah hasil pelatihan yang selama ini dilaksanakan belum bisa menghasilkan manfaat uyang signifikan terhadap peningkatan profesionalisme guru, karena dalam praktik pembelajarannya masih bersifat konvensional dalam arti lebih cenderung menekankan bagaimana guru mengajar (teacher-centered) daripada bagaimana siswa belajar (student-centered). Hasilnyapun belum bisa banyak memberikan kontribusi untuk peningkatan mutu dan proses hasil belajar siswa. Salah satu yang menjadi indikatornya terlihat dari hasil Penilaian Kinerja Guru (PKG) yang masih 
rendah untuk kompetensi pedagogik dan kompetensi profesional walaupun sudah sering dilaksanakan pelatihan guru.

Pada dasarnya ada tiga hal yang menyebabkan pelatihan guru belum berdampak pada peningkatan mutu pendidikan di SMPN 2 Talegong Kabupaten Garut-Jawa Barat, diantaranya: pertama, pelatihan yang selama ini berjalan tidak berbasis pada permasalahan nyata di dalam kelas; kedua, hasil pelatihan hanya dijadikan pengetahuan belaka tidak diterapkan pada pembelajaran yang sesungguhnya di dalam kelas ataupun kalau diterapkan hanya sekali, dua kali dan selanjutnya kembali seperti dulu lagi; ketiga, khusus untuk di daerah tertinggal seperti SMP Negeri 2 Talegong untuk mengikuti pelatihan yang dilaksanakan di luar sekolah terkendala oleh letak geografis sehingga untuk mengikuti kegiatan pelatihan memerlukan waktu yang terbuang cukup banyak, misalnya untuk mengikuti kegiatan pelatihan di tingkat Kabupaten Garut untuk perjalanannya saja memerlukan waktu 6-7 jam sekali jalan atau 12-14 jam untuk pulang pergi, kalau dihitung dengan hari terkadang untuk satu hari pelatihan dibutuhkan waktu tiga hari perjalanan. Hal seperti ini menjadikan kegiatan latihan kurang efektif.

Untuk mengatasi masalah ketidakefektifan kegiatan peningkatan kemampuan guru dalam pelaksanaan pembelajaran dan sekaligus mengatasi kelemahan pelatihan konvensional yang kurang menekankan pada pasca pelatihan maka penulis merencanakan model alternatif pelatihan lain dengan model in-sevice training yang lebih berfokus pada upaya pemberdayaan guru sesuai dengan kapasitas serta permasalahan yang dihadapi masing-masing. Model tersebut adalah Lesson Study Berbasis Sekolah yaitu suatu model pembinaan profesi pendidik melalui pengkajian pembelajaran secara kolaboratif oleh guru mata pelajaran yang berbeda dalam satu sekolah dan dilakukan secara berkelanjutan berdasarkan prinsip-prinsip kolegalitas dan mutual learning untuk membangun komunitas belajar.

Asal mula munculnya kegiatan lesson study adalah di Jepang, karena secara bahasa pun lesson study itu berasal dari bahasa jepang yaitu dari kata "jugyokenkyu" yang diartikan sebagai lesson study atau dalam bahasa indonesia disebut pengkajian terhadap pembelajaran. Lesson study menurut istilah, diungkapkan oleh Styler dan Hiebert merupakan suatu proses kolaboratif pada sekelompok guru ketika mengidentifikasi masalah pembelajaran, merancang suatu skenario pembelajaran (yang meliputi kegiatan mencari buku dan artikel mengenai topik yang akan di belajarkan), membelajarkan peserta didik sesuai skenario (salah seorang guru melaksanakan pembelajaran sementara yang lain mengamati), mengevaluasi dan merevisi skenario pembelajaran, membelajarkan lagi skenario pembelajaran yang telah direvisi, mengevaluasi lagi pembelajaran dan membagikan hasilnya dengan guru-guru lain. Adapun menurut Walker, lesson study merupakan suatu kegiatan pengkajian terhadap proses pembelajaran di kelas nyata yang dilakukan oleh sekelompok guru secara berkolaborasi dalam janghka waktu lama dan terus menerus untuk meningkatkan keprofesionalannya.

Dari beberapa pendapat diatas penulis membuat kesimpulan bahwa lesson study itu adalah model pembinaan guru dengan jalan mengkaji pembelajaran yang dilakukan secara kolaboratif dan berkesinambungan dengan dasar prinsip-prinsip kolegalitas dan mutual learning untuk membangun komunitas belajar di sekolah.

Pada pelaksanaannya Lesson study dapat dibedakan menjadi dua bentuk yaitu : 1) lesson study berbasis sekolah, yaitu lesson study yang dilakukan oleh seluruh guru dengan latar belakang bidang study yang berbeda dibantu oleh kepala sekolah, yang mempunyai tujuan agar kualitas proses dan hasil pembelajaran di sekolah dapat meningkat; 2) lesson study berbasis MGMP, yaitu lesson study yang dilaksanakan oleh kelompok guru mata pelajaran tertentu dengan pendalaman kajian tentang proses pembelajaran pada mata pelajaran tertentu yang dapatdilaksanakan pada tingkat wilayah, kabupaten atau mungkin bisa diperluas lagi.

Pelaksanaan Lesson Study Berbasis Sekolah ditekankan pada 3 tahap yaitu Plan (merencanakan atau merancang), Do (melaksanakan), dan See (mengamati, dan sesudah itu merefleksikan hasil pengamatan) (Sutopo dan Ibrohim, 2006). 


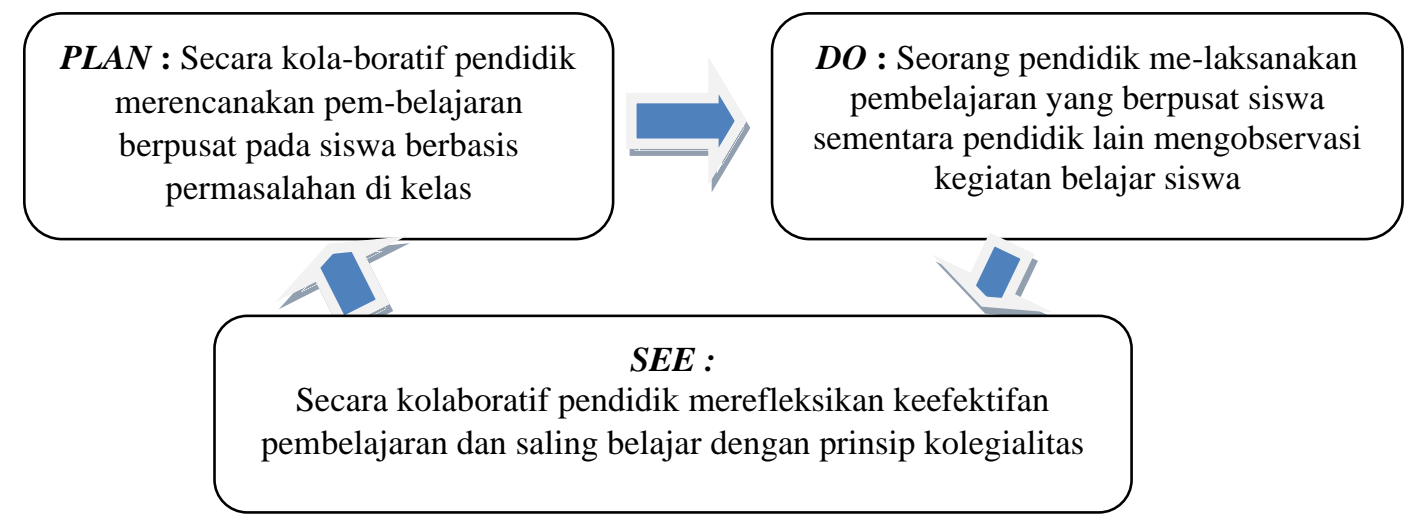

Gambar 1. Siklus Pengkajian Pembelajaran dalam Lesson Study di SMPN 2 Talegong

Guru profesional adalah guru yang memiliki kompetensi profesional, hal ini sejalan dengan Undang-Undang Nomor 14 Tahun 2005 tentang Guru dan Dosen, pada pasal 10 ayat (1), yang menyatakan bahwa kompetensi guru itu meliputi, kompetensi pedagogik, kompetensi profesional, kompetensi sosial, dan kompetensi kepribadian.

Sasaran yang ingin dicapai oleh SMPN 2 Talegong melalui kegiatan Lesson Study Berbasis Sekolah (LSBS) adalah mendongkrak profesiolisme guru sehingga meningkat pula kualitas pendidikan di SMPN 2 Talegong Kabupaten Garut - Jawa Barat.

\section{METODE}

Metode dan pelaksanaan best practice Lesson Study Berbasis Sekolah di SMPN 2 Talegong dilakukan secara kolaboratif dan berkelanjutan berdasarkan prinsip-prinsip kolegalitas dan mutual learning untuk membangun komunitas belajar. Adapun tahapan operasional pelaksanaan Lesson Study berbasis Sekolah di SMPN 2 Talegong adalah sebagai berikut: pertama,tahap pra-lesson tudy meliputi, kegiatan pembelakan, membentuk kelompok guru, menyusun jadwal, dan menetapkan guru model. Kedua, tahap pelaksanaan LSBS meliputi, plan (perencanaan), do (pelaksanaan), Tahap Refleksi, dan tahap tindak lanjut (act).

\section{HASIL DAN PEMBAHASAN}

\section{Prosedur Pelaksanaan}

Secara rinci kegiatan Lesson Study Berbasis Sekolah (LSBS) yang dilaksanakan di SMPN 2 Talegong adalah sebagai berikut:

Tahap pra-lesson study berupa kegiatan pembekalan sekaligus membangun komitmen bersama, hal ini dilaksanakan dengan tujuan untuk memberikan pemahaman yang utuh tentang kegiatan Lesson Study Berbasis Sekolah (LSBS) yang akan dilaksanakan sehingga tujuan pelaksanaan kegiatan bisa tercapai dengan baik. Kegiatan pembekalan ini dilaksanakan dengan mengadakan workshop dengan nara sumber kepala sekolah (Cucu Suwandana,.Pd.,M.Si).
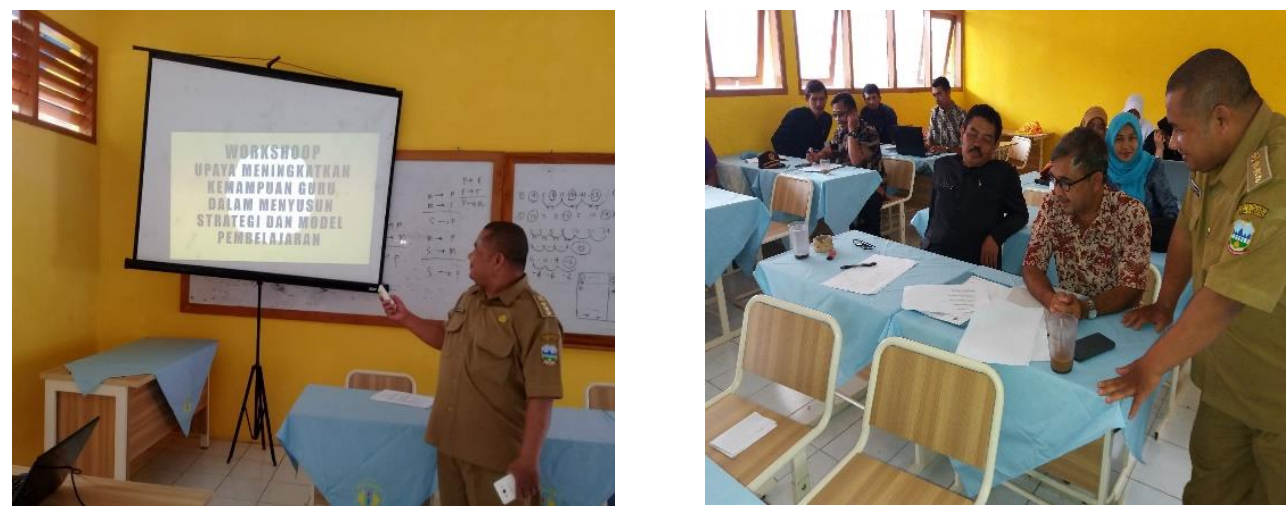

Gambar 2. Pelaksanaan pembelakan 


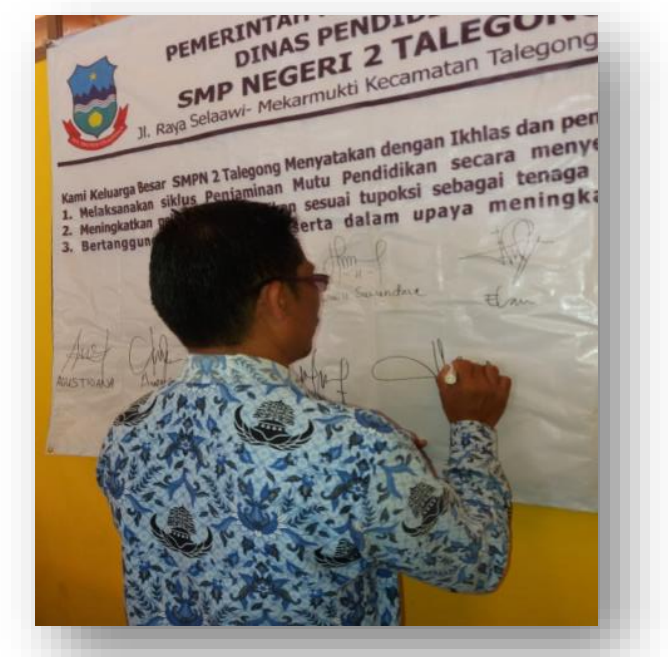

Gambar 3. Kegiatan membangun Komitmen Bersama

Masih pada tahap pra-lesson study kegiatan membentuk kelompok guru, Leson study yang dilaksanakan di SMPN 2 Talegong adalah lesson study yang berbasis sekolah artinya kelompok lesson study-nya terdiri dari beberapa guru yang berbeda mata pelajaran yang diampunya. Karena terdapat 22 guru maka kelompoknya di bagi dua kelompok. Tahap selanjutnya pada pra-lesson study adalah menyusun jadwal untuk kegiatan kelompok diskusi/refleksi RPP dan diskusi/refleksi observasi pembelajaran. Yang terakhir pada pra-lesson study adalah menetapkan guru model, Setiap guru ini secara bergiliran menjadi guru model di kelompoknya masing-masing.

Tahap pelaksanaan Lesson Study di SMPN 2 Talegong adalah sebagai berikut:

Tahap perencanaan (plan), pada tahap ini guru model secara bersama-sama dengan guru lain (observer) menyusun Rencana Pelaksanaan Pembelajaran (RPP)/lesson design. RPP yang disusun harus mempertimbangkan model/metode pembelajaran yang akan digunakan dan pembelajaran yang berpusat pada siswa. Perencanaan diawali dengan kegiatan menganalisis dan mengidentifikasi kebutuhan dan permasalahan yang mungkin akan dihadapi selama pembelajaran, seperti tujuan akhir dari pembelajaran yang ingin dicapai, bagaimana cara melakukan pembelajarannya, bagaimana mengantisipasi kekurangan alat peraga, dan lainnya. Sehingga didapatkan kondisi nyata yang akan dimanfaatkan untuk kegiatan pembelajaran. Kajian RPP harus bisa menjamin apakah indikator menjamin ketercapaian $\mathrm{KD}$, apakah tujuan pembelajaran relevan dengan indikator, apakah tujuan pembelajaran memenuhi kriteria ABCD (audience/siswa, behavior/tingkah laku hasil belajar, condition/kondisi, dan degree/target yang akan dicapai).

Setelah melakukan identifikasi, selanjutnya adalah secara bersama-sama mencari solusi untuk memecahkan permasalahan-permasalahan yang ditemukan. Kesimpulan dari hasil analisis dan identifikasi tersebut menjadi pertimbangan dalam menusun lesson design sehingga menjadi sebuah perencanaan yang matang.

Tahap kedua pada kegiatan pelaksanaan lesson study adalah pelaksanaan pembelajaran $(d o)$ atau kegiatan open lesson. Pada tahap open lesson terdapat dua kegiatan utama yaitu: pertama, kegiatan pelaksanaan pembelajaran yang telah dituangkan dalam RPP; kedua, kegiatan pengamatan atau observasi yang dilakukan anggota komunitas LSBS ( Kepala Sekolah, dan guru yang bertindak sebagai pengamat/observer). 
Beberapa hal yang diperhatikan dalam tahapan open lesson diantaranya : 1) Guru model melaksanakan pembelajaran sesuai dengan Lesson Design yang telah disusun pada tahap awal; 2) siswa melaksanakan proses pembelajaran secara wajar dan natural, tidak dalam keadaan tertekan akibat adanya kegiatan LSBS; 3) selama kegiatan open lesson, pengamat tidak berinteraksi dengan peserta didik, tidak mengganggu jalannya kegiatan open lesson, dan tidak mengganggu konsentrasi guru model maupun peserta didik; 4) yang diobservasi secara teliti oleh observer adalah bagaimana interaksi siswa dengan siswa, siswa dengan bahan ajar, siswa dengan guru, siswa dengan lingkungan lainnya; 5) Observer belajar dari pembelajaran yang berlangsung pada saat open lesson dan tidak untuk mengevalusi bagaimana guru model mengajar; 6) Observer melakukan perekaman melalui video camera atau photo digital untuk keperluan dokumentasi dan bahan analisis yang disampaikan pada saat melakukan refleksi; 7) Observer mencatat perilaku belajar siswa selama pembelajaran berlangsung, misalnya tentang komentar atau diskusi siswa dengan mencantumkan nama yang bersangkutan, terjadinya proses konstruksi pemahaman peserta didik melalui aktivitas belajar siswa.
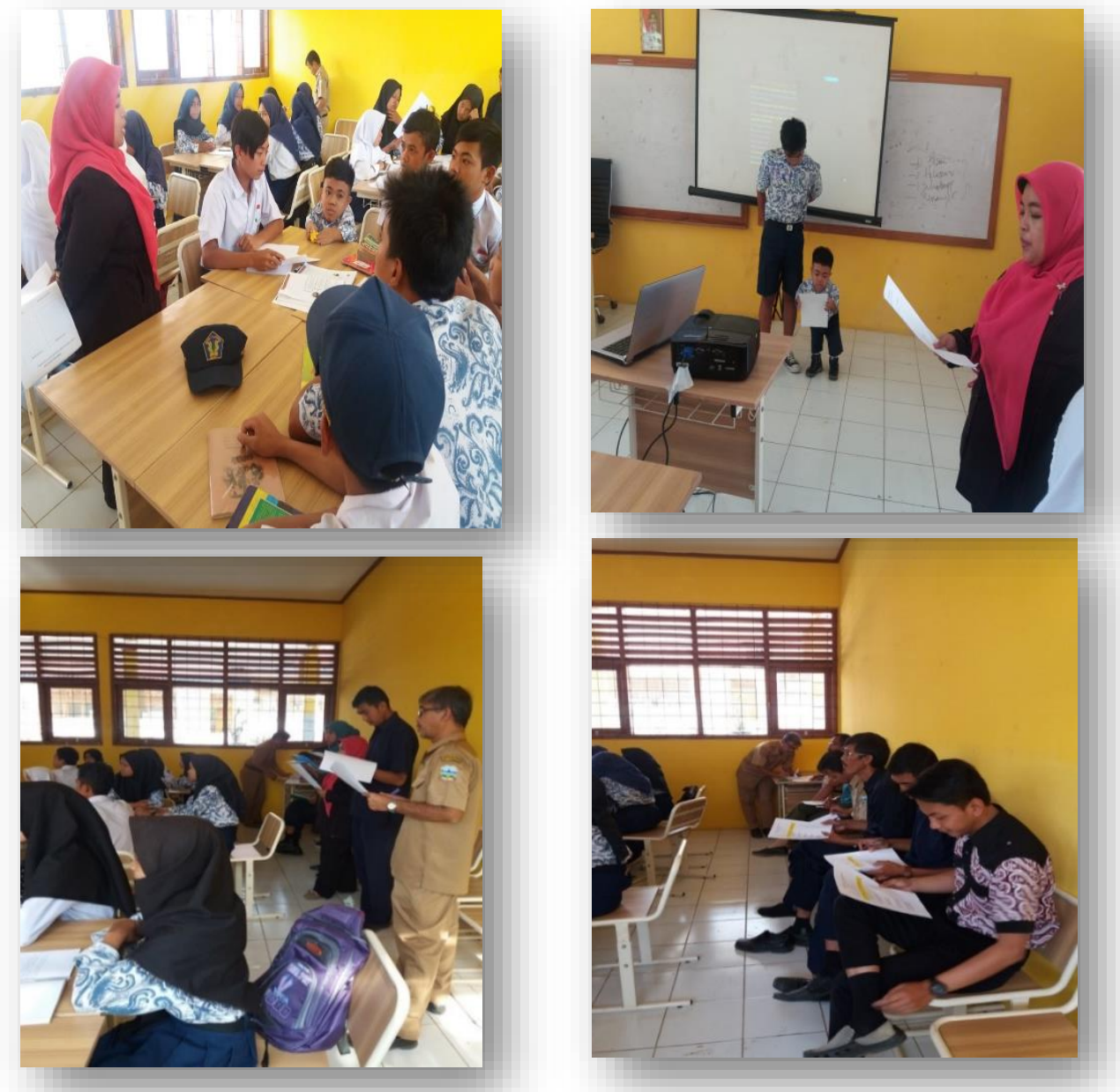

Gambar 4. Kegiatan oven Lesson

Tahap selanjutnya adalah melaksanakan refleksi, pada tahap refleksi ini kepala sekolah sebagai modersator dan kegiatan yang dilakukan adalah diskusi yang diikuti oleh seluruh komunitas lesson study. Diskusi dimulai dengan penyampaian praktik pembelajaran yang telah dilaksanakan oleh guru model untuk mengetahui kesan umum selama pembelajaran berlangsung.

Pada tahap ini disampaikan pula hambatan dalam melaksanakan lesson design yang telah disusun sehingga peseta diskusi dapat mengidentifikasi masalah-masalah yang timbul selama pembelajaran belangsung untuk didiskusikan bersama-sama. Setelelah guru model menyampaikan kesan umum selama pembelajaran berlangsung, semua peserta diskusi memberikan tanggapan atau saran secara bijak terhadap proses 
pembelajaran yang telah dilaksanakan (bukan terhadap guru yang bersangkutan). Dalam menyampaikan tanggapan dan saran, peserta diskusi menyampaikannya berdasarkan fakta yang terjadi berdasarkan pengamatan dan didukung oleh bukti-bukti, tidak berdasarkan opini. Berbagai pendapat yang berkembang selama diskusi dijadikan bahan refleksi bagi masing-masing peserta untuk perbaikan atau peningkatan proses pembelajaran pada mata pelajaran yang diampu.

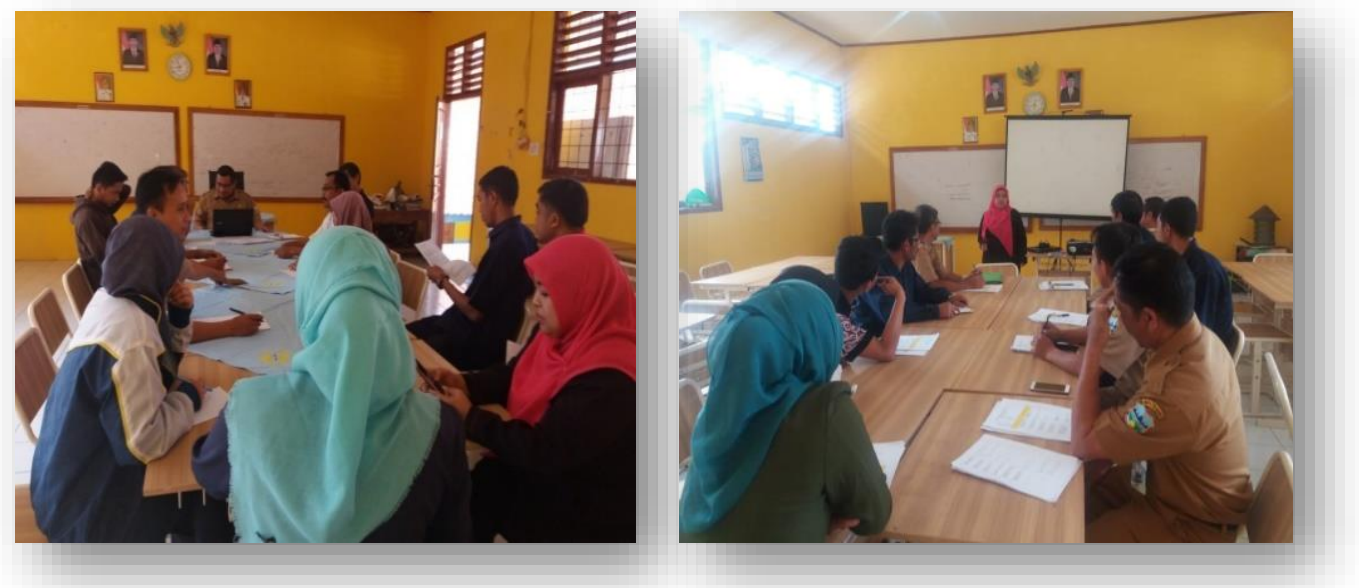

Gambar 5. Kegiatan Refleksi

Tahap keempat adalah tindak lanjut (act), Setelah melakukan refleksi terhadap proses pembelajaran, maka diperoleh poin-poin penting untuk perbaikan dan peningkatan proses pembelajaran, baik pada tataran guru sebagai pengajar, maupun pemangku kepantingan ( kepala Sekolah) sebagai penentu kebijakan. Pada tataran guru sebagai pengajar, berbagai temuan yang didapat pada saat diskusi tentunya menjadi modal yang baik untuk mengembangkan proses pembelajaran ke arah lebih baik. Sedangkan pada tataran pemangku kepentingan (kepala sekolah) sebagai penentu kebijakan, akan diperoleh sejumlah masukan yang berharga bagi kepentingan pengembangan manajemen pendidikan di SMPN 2 Talegong.

\section{Hasil}

Hasil yang dicapai dari kegiatan Lesson Study Berbasis Sekolah (LSBS) di SMPN 2 Talegong adalah :

Inovasi dalam perencanaan pembelajaran, hal ini terlihat dari kemampuan pengelola dalam perencanaan program Lesson Study Bebasis Sekolah hingga bisa membawa dampak yang positif bagi kemajuan sekolah baik dari segi manajerial ataupun secara perorangan sebagai guru daalam meningkatkan kualitas hasil dan proses pembelajaran di dalam kelas. LSBS ini bertujuan untuk mengembangkan profesionalisme guru oleh karena itu pelaksanannnya memerlukan pemahaman dan mengetahui tujuan yang akan dicapai, selain itu LSBS bukan sekedar untuk mengatasi masalah pembelajaran di dalam kelas tetapi lebih kepada membangun suatu jalur atau pola untuk mengatasi kegiatan instruksional yang sedang berjalan. Hasil yang terlihat di SMPN 2 Talegong dalam perencanaan pembelajaran adalah dimulai dari penyusunan program kegiatan lesson study berbasis sekolah oleh tim pengembang yang kemudian dibahas bersama dalam rapat awal tahun pelajaran 2018/2019, pemilihan guru model yang sudah terjadwal secara bergiliran, dan pembuatan RPP secara kolaboratif.

Inovasi dalam pelaksanaan pembelajaran, hal ini terlihat dari kegiatan guru dalam melaksanakan pembelajaran sudah menggunakan metode dan media yang bervariasi, sudah terjalin kerjasama yang baik dan saling belajar baik antara guru dengan guru maupun antara kepala sekolah dengan guru, dan guru sudah melaksanakan open lesson secara terjadwal. 
Inovasi dalam evaluasi pembelajaran, ketika kita melakukan evasluasi itu artinya kita melakuman suatu proses atau kegiatan pemilihan, pengumpulan, analisis dan penyajian informasi yang dapat digunakan sebagai dasar pengambilan keputusan serta penyusunan program selanjutnya. Menurut Cepi Safarudin dalam Widoyoko Eko Putro (2012:6) ada 4 kemungkinan kebijakan yang dapat dilakukan berdasarkan hasil evaluasi program, yaitu: (1) menghentikan program, karena program tersebut tidak ada manfaatnya, atau tidak bisa terlaksan sebagaiman mestinya; (2) memperbaiki program, hal ini dilakukan karena ada bagian-bagian yang kurang sesuai dengan yang diharapkan: (3) melanjutkan program, hal ini dilakukan karena pelaksanaan program menunjukkan bahwa segala sesuatunya sudah berjalan sesuai dengan yang diharapkan dan sudah memberikan hasil yang bisa bermanfaat; (4) menyebarkan program, hal ini dilakukan karena program yang berjalan berhasil dengan baik, oleh karena itu sangat baik jika dilaksanakan lagi di tempat dan waktu yang lain. Evaluasi pembelajaran dilaksanakan dengan tujuan untuk memantau keberhasilan atau dampak dari pelaksanaan kegiatan lesson study berbasis sekolah terhadap kualitas pembelajaran di kelas. Dalam melaksanakan evaluasi pembelajaran perlu dilakukan suatu inovasi agar dapat merangsang motivasi siswa untuk mengikuti evaluasi pembelajaran dan memperoleh hasil yang memuaskan. Evaluasi yang dilakukan oleh guru dalam melaksanakan evaluasi pembelajaran adalah dengan berbagai metode evaluasi. Evaluasi pembelajaran perlu sekali dilakukan untuk melihat sejauh mana siswa memahami pelajaran yang telah disampaikan. Evaluasi yang menarik juga diperlukan suatu inovasi atau menggunakan metode yang bervariasi sehingga pelaksanaan evaluasi tidak terasa monoton bagi siswa. Evaluasi ini dilakukan untuk mengukur ketercapaian pemahaman siswa terhadap pelajaran yang sudah diberikan, yang mana hasilnya akan berdampak positif bagi proses pembelajaran selanjutnya, karena dengan diadakannya evaluasi ini maka diharapkan bisa mengetahui kelebihan dan kelemahan dari kegiatan pelaksanaan pembelajaran melalui Lesson Study berbasis sekolah ini dan memperbaiki kualitas pelaksanaan kegiatan Lesson Study selanjutnya yang juga akan berdampak pada peningkatan mutu guru dan kualitas pembelajaran. Hasil yang didapat di SMPN 2 Talegong dalam hal evaluasi terlihat dari kegiatan evaluasi pembelajaran yang dirancang secara kolaboratif, evaluasi dilaksanakan sebelum, selama, dan setelah pembelajaran pada setiap open lesson, serta guru sudah melaksanakan evaluasi pembelajaran dengan berbagai metode yang bervariatif dan inovatif.

Inovasi dalam pengawasan pembelajaran, menelaah tentang kepengawasan maka kepengawasan mempunyai pengertian suatu proses untuk menetapkan pekerjaan apa yang sudah dilaksanakan, menilainya dan mengoreksi bila perlu dengan maksud supaya pelaksanaan pekerjaan sesuai dengan rencana semula. Tujuan utama dari kepengawasan adalah mengusahakan agar apa yang direncanakan menjadi kenyataan. Inovasi dalam kepengawasan di SMPN 2 Talegong pada program LSBS terlihat dari kegiatan kepala sekolah yang secara rutin memeriksa setiap perangkat pembelajaran guru model yang akan melaksanakan open lesson, selain itu kepala sekolah secara rutin melaksanakan observasi pada setiap guru yang melaksanakan open lesson.

\section{Dampak pelaksanaan kegiatan Lesson Study berbasis Sekolah (LSBS)}

Inovasi pengelolaan pembelajaran melalui kegiatan Lesson Study Berbasis Sekolah (LSBS) sangat berdampak positif baik terhadap para guru maupun terhadap kehidupan/budaya sekolah. Dampak terhadap guru setelah dilakukannya kegiatan lesson study secara periodik, diantaranya :

Meningkatnya kemampuan guru dalam menguasai karakteristik siswa baik dari aspek fisik, moral, spiritual, sosial, kultural, emosionalm dan intelektial. Hal ini terjadi karena lesson study yang dilakukan memberi kesempatan pada guru (observer) untuk dengan cermat meneliti proses belajar serta pemahaman siswa dengan cara mengamati 
dan mendiskusikan praktek pembelajaran di dalam kelas. Kesempatan ini juga memperkuat peran guru sebagai peneliti didalam kelas. Guru bisa melakukan hipotesis, sebagai salah satu contoh misalnya jika saya melakukan pembelajaran dengan cara terrtentu maka siswa akan belajar dengan serius, nyaman, tenang, dan menyenangkan. Kemudian guru mengumpulkan data ketika melakukan pengamatan terhadap siswa selama berlangsungnya pelajaran dan menentukan apakah hipotesis itu terbukti atau tidak di kelas. Kegiatan ini dilakukan secara terus menerus secara otomatis akan membuat guru semakin trampil dalam memahami karakteristik peserta didik.

Meningkatnya kemampuan guru dalam menguasai teori belajar dan prinsipprinsip pembelajaran yang mendidik, hal ini terlihat dari perkembangan guru-guru yang lebih kreatif, terbiasa berkolaborasi dan saling membantu dalam merancang pembelajaran sehingga perangkat pembelajaran lebih berkualitas dan lengkap. Selain itu guru juga lebih profesional dalam memilih media atau metode pembelajaran. Hal ini akan mengakibatkan siswa lebih semangat dan aktif dalam kegiatan pembelajaran.

Meningkatnya kemampuan guru dalam memanfaatkan teknologi informasi dan komunikasi untuk kepentingan pembelajaran, Hal ini sangat penting karena guru merupakan satu bagian yang terpenting dalam proses pembelajaran di kelas, sehingga dibutuhkan sosok guru yang kreatif, inovatif, dan penuh dengan inspiratif dalam setiap melaksanakan pembelajaran, selain itu mampu memanfaatkan teknologi informasi dan komunikasi dalam proses pembelajaran. Penulis mengamati pada saat ini masih sangat memprihatinkan khususnya di daerah tertinggal guru masih banyak yang belum bisa memanfaatkan teknologi informasi bahkan penguasaan materipun masih kurang dan terkesan tidak menarik, karena hanya mengandalkan ilmu yang didapatkannya tanpa mengelaborasikan informasi di sumber-sumber yang lain seperti buku yang relevan, internet, koran, majalah, TV dan lainnya. Kalau guru sudah mampu mengelaborasikan informasi dari berbagai sumber maka guru akan mampu menciptakan materi yang sulit menjadi mudah dipahami oleh siswa, yang akhirnya akan tercipta suasana belajar yang nyaman, senang, dan materi yang disampaikan mudah untuk dipahami berkat bantuan teknologi informasi.

Dalam setiap kegiatan open lesson hampir setiap guru berusaha untuk menggunakan proyektor sehingga penggunaan teknologi informasi menjadi hal yang biasa. Guru mampu memfasilitasi pengembangan potensi siswa untuk mengaktualisasikan berbagai potensi yang dimiliki karena guru sering menggunakan model pembelajaran yang bervariasi yang mendorong siswa mencapai prestasi secara optimal dan mengaktualisasikan potensi dan kreatifitasnya.

Meningkatkan kemampuan guru dalam menguasai materi, struktur, konsep, dan pola pikir keilmuan yang mendukung mata pelajaran yang diampu. Hal ini diakibatkan kebiasaan guru dalam mendalami materi ajar yang dilakukan secara kolaboratif, saling tukar pengalaman dibantu oleh kepala sekolah sehingga pengetahuan guru tentang materi akan lebih baik dan meningkat. Meningkatnya kemampuan guru dalam mengembangkan keprofesionalan secara berkelanjutan (PKB) dengan melakukan tindakan reflektif. Setelah kegiatan lesson study berjalan hampir setiap guru termitivasi untuk membuat karya tulis baik berupa Penelitian Tindakan Kelas (PTK) maupun membuat best practices guru. Dari data yang diperoleh sebelumnya hanya $14 \%$ guru yang membuat karya tulis melonjak menjadi $86 \%$ guru membuat karya tulis.

Meningkatnya hubungan kolegialitas, Lesson study di SMPN 2 Talegong dibagi dua kelompok yang masing-masing terdiri dari 10 angota. Masing-masing kelompok dalam satu putanan akan bertemu sebanyak 10 kali plan,10 kali Do dan 10 kali refleksi, atau dalam satu putaran akan bertemu minimal $30 \mathrm{kali}$, ini artinya bahwa akan menambah semakin kuatnya hubungan kolegialitas.

Meningkatnya kemampuan berkomunikasi secara efektif, empatik, dan santun dengan sesama guru. Hal yang paling penting dalam kompetensi sosial adalah 
komunikasi, karena inti dari tindakan sosial itu sendiri adalah komunikasi atau interaksi. Dalam kompetensi sosial ini seorang guru dituntut untuk melakukan komunikasi yang efektif dengan siswa, sesama guru, orang tua siswa, dan masyarakat sekitar. Dalam kegiatan lesson study kemampuan berkomunikasi guru akan terlihat saat siswa merespon penjelasan guru model dan akan terekam oleh seluruh observer yang nantinya akan dibhas dalam kegiatan refleksi. Karena kegiatan ini dilakukan secara terus menerus maka bisa meningkatkan kemampuan guru dalam berkomunikasi.

Adapun dampak terhadap kehidupan/budaya sekolah sangat terlihat jelas dari kondisi sekolah yang semakin terlihat berkembang, diantaranya:

Terbangunnya komunitas belajar di lingkungan sekolah yang bermanfaat untuk meningkatkan kefektifan komunikasi sekolah dalam rangka memperbaiki kualitas pembelajaran. Meningkatnya publikasi ilmiah guru dari hasil-hasil pengembangan pembelajaran melalui lesson study berbasis sekolah, hal ini terlihat dari banyaknya hasil publikasi ilmiah guru yang disimpan di perpustakaan sekolah sebagai syarat untuk kenaikan pangkat guru.

Meningkatnya kepercayaan masyarakat terhadap sekolah, dua indikator yang bisa dijadikan dasar meningkatnya kepercayaan masyarakat yaitu dari sudut pertambahan peserta didik yang melanjutkan ke SMPN 2 Talegong dan adanya sumbangan dari orang tua untuk meningkatkan kualitas sekolah.

Tercapainya sasaran kinerja ASN, setiap awal bulan januari setiap tahun seluruh guru ASN membuat sasaran kinerja untuk satu tahun kedepan, dan setiap akhir tahun dinilai target pencapainnya yang akan dijadikan angka kredit tahunan. Setelah berjalannya kegiatan lesson study berbasis sekolah berjalan kebiasaan guru untuk memenuhi target yang akan dicapai dalam Sasaran Kinerja pegawai (SKP) sudah menjadi tradisi.

\section{Masalah yang ditemukan selama pelaksanaan Lesson Study Berbasis Sekolah (LSBS) di SMPN 2 Talegong}

Beberapa permasalahan yang ditemukan selama pelaksanaan kegiatan Lesson Study Berbasis Sekolah di SMPN 2 Talegong diantaranya :

Masih ada jadwal observer yang bentrok antara jadwal mengajar di kelas dengan jadwal lesson study sehingga terpaksa harus memberi tugas kepada siswanya di kelas yang bersangkutan, Masih ditemukan guru yang belum siap menjadi guru model dengan alasan belum siap untuk diobservasi oleh rekan-rekan sejawat, Masih terbatasnya anggaran yang disediakan pihak sekolah untuk kegiatan lesson study berbasis sekolah sehingga belum mampu mengundang tenaga ahli/para pakar atau dari perguruan tinggi yang bisa menjadi observer atau nara sumber dalam sosialisasi mengenai lesson study.

\section{Solusi untuk mengatasi permasalahan yang ditemukan selama pelaksanaan Lesson Study Berbasis Sekolah (LSBS) di SMPN 2 Talegong.}

Untuk mengatasi permasalahan jadwal yang masih bentrok wakasek kurikulum mengatur jadwal sehingga resiko bentrok antara jam mengajar dengan jadwal lesson study tidak berbentura.

Untuk mengatasi permasalahan guru yang belum siap menjadi guru model dengan alasan belum siap diobservasi oleh teman sejawat maka guru tersebut selalu diberi motivasi, diberi dukungan, dan berangsur-angsur diberikan pemahaman mengenai pentingnya kegiatan lesson study untuk meningkatkan profesionalisme guru.

Untuk mengatasi permasalahan terbatasnya anggaran maka kepala sekolah berkomitmen untuk selalu mempersiapkan anggaran untuk kegiatan LSBS dan akan berusaha untuk melakukan pendekatan-pendekatan dengan para pakar atau perguruan tinggi untuk menjadi nara sumber dalam sosialisasi LSBS. 


\section{KESIMPULAN}

Kegiatan Lesson Study Berbasis Sekolah (LSBS) di SMPN 2 Talegong telah dilaksanakan sesuai dengan ketentuan dan norma yang berlaku di sekolah, adapun simpulan dari kegiatan ini adalah sebagai berikut:

Pertama, perencanaan pembelajaran melalui Lesson Study berbasis sekolah yang dibuat secara kolaboratif oleh guru-guru dalam kelompok Lesson Study yang akan tampil.

Kedua, dengan adanya program pengelolaan pembelajaran melalui Lesson Study berbasis sekolah di SMP Negeri 2 Talegong ini maka para guru dapat melaksanakan pembelajaran yang lebih inovatif dan meningkatkan kualitas pembelajaran mereka, terjalin kerjasama yang baik dan saling belajar antar guru dan kepala sekolah serta guru dapat melaksanakan open lesson secara terjadwal.

Ketiga, Evaluasi pembelajaran melalui Lesson Study berbasis sekolah ini dirancang secara kolaboratif oleh guru-guru sehingga menghasilkan metode evaluasi yang bervariasi. Evalauasi ini dilaksanakan dalam setiap pelaksanaan open lesson.

Keempat, Kepengawasan terhadap kegiatan LSBS ini dilaksanakan oleh kepala sekolah dengan cara menilai dan memeriksa kesiapan administrasi pembelajaran kelompok Lesson Study sebelum open lesson dan ikut aktif berpartisipasi dalam setiap tahapan Lesson Study yaitu plan, do, dan see.

Kelima, banyak dampak yang telah dirasakan setelah melaksanakan Lesson Study berbasis sekolah ini, antara lain kompetensi guru semakin meningkat baik kompetensi pedagogik, kompetensi profesional, kompetensi kepribadian maupun kompetensi sosial, Terbangunnya komunitas belajar di lingkungan sekolah, Meningkatnya publikasi ilmiah guru, Meningkatnya kepercayaan masyarakat terhadap sekolah, dan Sasaran kinerja PNS yang dikontrak tiap awal tahun ( Bulan Januari ) dapat tercapai diakhir tahun.

Keenam, dalam melaksanakan Lesson Study berbasis sekolah ini masih ditemui berbagai permasalahan, yaitu; masih ada jadwal yang bentrok antara jadwal mengajar dengan jadwal LSBS, masih ditemui guru yang belum mau menjadi guru model, dan masih terbatasnya anggaran untuk kegiatan lesson study.

Ketujuh, sekolah berkomitmen untuk membuat jadwal kegiatan LSBS yang paling efektif agar tidak ada lagi jadwal yang bentrok, sekolah berkomitmen juga untuk selalu memotivasi dan memberi dukungan kepada seluruh warga sekolah agar membudayakan lesson study dalam berupayan meningkatkan profesionalisme guru.

Untuk mencapai keberhasilan dalam kegiatan lesson study berbasis sekolah ini, pihak sekolah hendaknya bekerjasama dengan para pakar atau perguruan tinggi untuk mengadakan pelatihan atau workshop tentang Lesson Study.

\section{DAFTAR PUSTAKA}

Cerbin, Bill Cerbin \& Bryan Kopp. A Brief Introduction to College Lesson Study. Lesson Study Project. online: http ://www.uwlax.edu/sotl/lsp/index $2 . \mathrm{htm}$

Departemen Hukum dan HAM RI.2005.Undang-undang Nomor 14 tahun 2005 tentang Guru dan Dosen.Jakarta:Departemen Hukum dan HAM RI.

Faiq, Muhammad 2008.'Lesson Study: mengapa Lesson Study?". Makalah Online:http://www.fromlearningtoteaching.blogspot.com/search/label/lesson\%20stud y

http://wwwpembelajaranguru.wordpress.com/2008/05/22/lesson-study-dasar-pemikiranpenyusunan-perangkat-pembelajaran

Hendayana S.. 2006. Lesson Study Suatu Strategi untuk Meningkatkan Keprofesionalan Guru (Pengalaman JUSTEP-JICA). Bandung: UPI Press.

Sumar, Hendayana, dkk. 2007 Lesson Study: Suatu Strategi Untuk Meningkatkan Keprofesionalan Pendidik (Pengalaman IMSTEP-JICA). Bandung: UPI Press

http://www.aguswuryanto.files.wordpress.com/2008/09/lesson-study-dijepang.doc dalam http://www.google.co.id/search?hl=id\&client=firefox- 
a\&chanel=s\&rls=org.mozilla:en-

US:official\&hs=sDx\&sa $=X \&$ oi $=$ spell \&resnum $=0 \& \mathrm{ct}=\mathrm{result} \& \mathrm{~cd}=1 \& \mathrm{q}=$ sekilas + tenta ng+pelaksanaan+lesson+study+di+jepang+makoto+yoshida\&spell=1

Lewis, Catherine. 2004.Does Lesson Study Have a Future in the United States?. Online:http://uwlax.edu/sotl/lsp/index2.htm

Mulyana, Deddy. 2007.Ilmu Komunikasi: Suatu Pengantar.cetakan ke-9.Bandung:PT Remaja Rosdakarya

Mulyana, Slamet. 2007."lesson Study.” Makalah.Kuningan:LPMP-Jawa Barat

Peraturan Menteri Pendidikan Nasional Republik Indonesia No 16 Tahun 2007 tentang Standar Kualifikasi Akademik dan Kompetensi Guru

Yoshida, Makoto. 2007.'Sekilas TentangPelaksanaan Lesson Study di Jepang”.terjemahaan Muchlas Yusak,Widyaiswara LPMP Jateng, 2008.Makalah: bahan In House Training Lesson Study 9-11 Maret 2007, LPMP Jawa Tengah. Online: http://lpmpjateng.co.id Putro, Widarso Pujianto Eko .2008."Peningkatan Profesionalisme Guru melalui Lesson Study". Makalah Online: http://researchengines.com/0308windarso.html

Roebyarto.2008."'suatu Model untuik Peningkatan Kualitas Pembelajaran di

Sekolah".makalah Online: http://www.roebyanto.multiply.com/journal/item/18

Sapa'at, Asep. 2008." Membangun Lesson Study di SMA Pertama Mansamat, Kepulauan Banggai".Makalah Online:

http://sahabatguru.wordpress.com/2007/09/14/membumukan-lesson-study-di-smapertama-mansamat-kep-banggai/

Akhmad Sudrajat.2008.'Lesson Study untuk meningkatkan Proses dan Hasil Pembelajaran”. Makalah online:http://www.akhmadsudrajat.wordpress.com

Muchlas Yusak. 2008.'Lesson Study: Pengembangan Profesional Guru secara Berkelanjutan Berbasis Sekolah". Makalah online:http://www.lpmpjateng.go.od

Rohim, Bima dan Julian. 2016. Belajar dan Pembelajaran di Abad 21. Makalah Untuk Memenuhi Tugas Mata Kuliah Kajian Media Pembelajaran. Kurikulum dan Tenologi Pendidikan. Fakultas Ilmu Pendidikan. Universitas Negeri Yogyakarta. 